\title{
Do PostGraduate Doctors Have Special Coping Against Stress?
}

\author{
Mamidipalli SS1, Gupta AK², Mandal S3 , Rai N", Niraula A ${ }^{5}$
}

1. Senior Resident, Department of Psychiatry, AIIMS, Raipur, India 2. Lecturer, Department of Psychiatry, NMC-TH,, Birgunj, Parsa, Nepal 3. Assistant professor, Department of psychiatry, AIIMS, Raipur, India 4. Assistant Professor, KIST Medical college, Kathmandu, Nepal 5. Consultant, Birta city Hospital, Jhapa, Nepal

E-mail *Corresponding author :dranoopkrn@gmail.com

\begin{abstract}
Introduction: The aim of this study was to assess the level of perceived stress and identify coping strategies associated with it in postgraduate doctors. We also wanted to assess association among various socio-demographic variables, stream of post-graduation, level of stress and type of coping.

Material And Method: This was a cross sectional assessment by online survey on convenient samples of 99 post graduate doctors (completed MD degree in both clinical and non-clinical stream) working in various medical colleges in two countries i.e. India and Nepal. The main scales used were Perceived Stress Scale (PSS) and Brief COPE.

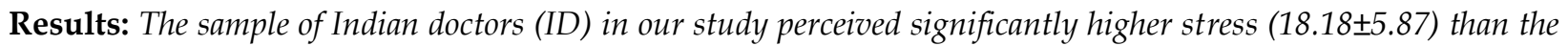
sample of Nepalese doctors (ND) (14.4 \pm 6.68 ). Coping strategies in the sample of ID tend to become more of 'avoidance' type when stress level increased to moderate-severe stress unlike ND \{1.802(p0.075)\}. The result of correlation analysis was in alignment with the above findings.

Conclusion: There is significant stress among post graduate doctors in any stream. There are several faulty coping types that have potential to hamper the decision-making capacity of a doctor. These issues need to be addressed in order to increase the efficiency of doctors either in clinical or in non-clinical specialties. Thus, we can save the saviors from the ill-effects of stress and make them function effectively and improve their quality of life.
\end{abstract}

\section{Keywords: Stress, Coping, Post-Graduate Doctors}

\section{INTRODUCTION}

Medical practice is a sensitive issue as it deals with life of human beings directly. So, the amount of stress it renders on doctors who are considered the immediate cause of life or death of patients is high. The stress further increases when one has to work in the Indian subcontinent setup which has poorly protected hospital environment. Recent increases in abuse and fatal attacks upon doctors ${ }^{1,2}$ have added to their stress in countries like India and Nepal where culture and medical practice resonate and affect each other.

Stress among doctors, either in resident doctors ${ }^{3}$, emergency physicians ${ }^{4}$ or among cardiac surgeons ${ }^{5}$ was studied in past. There are many studies among Asian doctors which include interns $^{6}$, physicians ${ }^{7}$, residents ${ }^{8,9,10}$ and all 
doctors. ${ }^{11}$ Indian data is abundant while those from Nepal are few and contain medical students only. 12,13

However, we could not find a single study encompassing clinical and non-clinical postgraduate doctors from heterogeneous sample. As to our knowledge there are few studies which included post-graduate doctors of all the specialities and none from different geographical regions. Inclusion of sample from varied nations helps us not only to understand the gross difference among the stress levels and the coping patterns, but also to make the result more acceptable. There is also a need to understand the differences in the coping factors used by them depending upon the area of work. This is believed to help in designing specific management strategies.

Therefore, we wanted to see perceived stress and coping strategies among postgraduate doctors who are working in medical colleges in two neighbouring countries i.e. India and Nepal, and compare them on several sociodemographic and clinical variables. These two countries share a border where locomotion is free. We designed the study to learn the current state of stress and guide the stakeholders with better coping skills in deficit areas. It is a step in the path of addressing a doctor's psychological well being

\section{MATERIAL AND METHOD}

This was a cross sectional survey conducted over a period of three months (February-April 2017). The principal investigators were from two countries i.e. India \& Nepal. Permission for conduction of the study was taken from the ethics committee of the principal medical college.

An online survey in English language was sent to participants using www.kwiksurveys.com. Each questionnaire included assessment of socio-demographic variables, psychiatric 'caseness' by GHQ-12, degree of perceived stress by Perceived stress scale (PSS), and coping patterns by using Brief-COPE. The information about the survey was circulated through popular social media like Messenger, Facebook, WhatsApp, Viber and e-mails. Only one reminder was sent to those doctors who either did not respond or had responded incompletely.

\subsection{Participants}

The survey was circulated to a total of 250 postgraduate doctors of any age group, either gender and to both clinical \& non-clinical departments of 23 and 6 medical colleges in India and Nepal respectively. It included both government and private institutions. Out of 250, we received 113 responses overall. However, 4 of them scored GHQ positive. We excluded them from our analysis because we thought that might confound the data about the reason for stress. Additional ten responses were not included in the analysis as they were incomplete even after reminder. So, the final sample size was 99. As these questionnaires were self-report of the participants, their consent was implied. No additional benefit was provided to the participants. Strict confidentiality of the responses and participants' identity were maintained.

\subsection{Instruments of the study \\ 1.2.1. General health Questionnaire-12 (GHQ-12)}

This widely used scale was developed by Goldberg to measure general distress. It is used as a screening tool for general psychological health rather than depression,anxiety or any particular psychiatric disorder. Each item is rated on a four-point (0-0-1-1) scale. The cut off score was less than or equal to 2 to deny psychiatric 'caseness'. All those who had scored more or equal to 2, were considered to be suffering from psychological morbidity i.e. they were labeled as psychiatric case and excluded from analysis. Its internal consistency is satisfactory i.e. cronbach alfa is between .82 and .86[14].

\subsubsection{Perceived stress scale (PSS)}

It is a self-administered scale in English which is used to assess the degree of perceived stress over the past 1 month. It consists of 10 questions. Scoring for each item ranges from 0 (never) to 4 (very often). Individual score on PSS range from $0-40$ with higher score indicating higher perceived stress. It is easy to apply and takes less time for completion. The test-retest reliability of the PSS-10 has been assessed, and is above .70 as per a review by Lee. In the same review, the Cronbach's alfa has been shown to range from .74 to $.91^{[15]}$.

\subsubsection{Brief- COPE}

Coping strategies for the perceived stress were assessed using the 28 item Brief COPE scale. It 
assesses 14 coping strategies from the 28 questions i.e. 2 questions per strategy. Each question is answered in a 4-point Likert-type scale. Total score for each question ranges from 1 to 4 and for each strategy from 2 to 8 . It includes both adaptive and maladaptive strategies of coping. The scale has good validity and internal consistency.Cronbach's alpha coefficients ranged from 0.71 to 0.82 for three to four dimensions ${ }^{[16]}$.

\subsection{Statistical analysis}

We used SPSS version 16.0 for the analysis purpose. Descriptive analysis was carried out using mean and standard deviation for continuous variables, including sociodemographic profile, clinical parameters and scores on the different scales. Descriptive analysis was computed in terms of frequency and percentages for categorical sociodemographic and psychological variables.

Univariate analysis was carried out to assess the association between different correlates and coping mechanisms. It was done either for categories (gender and country) or for continuous variables such as score on PSS. Student's t test, Mann-Whitney test, Spearman's correlation coefficients, Pearson's correlation coefficients, Chi-square tests, and Fisher's Exact Test were used for studying these associations as required.

\section{RESULT}

\subsection{Socio-demographic profile (Table 1)}

In overall sample of 99, 72 were from India and 27 were from Nepal. Males were in higher proportion, accounting to $65 \%$ overall. Most of the participants (98\%) were younger than 50 years of age. Around seventy nine percent of the subjects were from clinical background whereas the rest was from non-clinical settings. $57 \%$ of the sample was single at the time of conducting the survey. Most of them (96\%) had a work experience of less than 10 years.

From Table 1, it is evident that higher number of Indian Post graduate doctors were single compared to Nepalese doctors. However, the proportion of males \& females, duration of work experience, age and the subject of specialisation was found to be similar in both the groups.
Table 1: Comparison of socio-demographic profile among India and Nepal

\begin{tabular}{|c|c|c|c|}
\hline Variables & $\begin{array}{c}\text { India } \\
\text { n/\% }\end{array}$ & $\begin{array}{c}\text { Nepal } \\
\text { n/\% }\end{array}$ & $\begin{array}{c}\text { Chi square/ } \\
\text { t-test } \\
\text { (p value) }\end{array}$ \\
\hline $\begin{array}{c}\text { Marital status } \\
\text { Single } \\
\text { Married } \\
\end{array}$ & $\begin{array}{l}49(68) \\
23(32) \\
\end{array}$ & $\begin{array}{c}8(30) \\
19(70) \\
\end{array}$ & $11.870(0.001)^{* *}$ \\
\hline $\begin{array}{c}\text { Gender } \\
\text { Male } \\
\text { Female } \\
\end{array}$ & $\begin{array}{l}46(63) \\
26(37) \\
\end{array}$ & $\begin{array}{c}19(70) \\
8(30)\end{array}$ & $0.366(0.545)$ \\
\hline $\begin{array}{l}\text { Duration of } \\
\text { experience }\end{array}$ & $\begin{array}{c}1.15 \pm \\
0.73 \\
\end{array}$ & $\begin{array}{c}1.29 \pm \\
0.72 \\
\end{array}$ & $0.878(0.382)$ \\
\hline $\begin{array}{ll}\text { Age } & \\
& <50 \\
& >50 \\
\end{array}$ & $\begin{array}{c}71(99) \\
1(1) \\
\end{array}$ & $\begin{array}{c}26(96) \\
1(4) \\
\end{array}$ & $0.473 \#$ \\
\hline $\begin{array}{l}\text { Post-graduation } \\
\text { stream } \\
\text { Clinical } \\
\text { Nonclinical }\end{array}$ & $\begin{array}{l}58(80) \\
14(20)\end{array}$ & $\begin{array}{c}20(74) \\
7(36)\end{array}$ & $0.494(0.482)$ \\
\hline
\end{tabular}

\subsection{Comparison of degree of perceived stress} (Table 2)

Score of perceived stress was found to be significantly higher in the sample of Indian doctors included compared to that of the sample of Nepalese doctors. Also, the number of doctors who fell under the category of moderate/high stress was significantly higher from subset of doctors from India compared to Nepal. However, in the overall sample marital status was not associated with the degree of perceived stress. Though the mean score of perceived stress was higher in doctors with lesser duration of experience, but the difference didn't turn out to be statistically significant.

In next step we tried to find out association between PSS score and either of marital status, duration of experience and stream of postgraduation. It was found that neither the subset of Indian doctors nor the subset of Nepalese doctors had any association between degree of perceived stress and marital status, duration of experience or subject of post-graduation. 
Table 2: Country-wise score of Perceived Stress Scale (PSS) score

\begin{tabular}{|c|c|c|c|c|}
\hline \multicolumn{2}{|l|}{ Variables } & $\begin{array}{c}\text { India } \\
\text { (mean } \\
\pm \mathrm{SD}) \\
\text { or } \\
\%(\mathrm{~N})\end{array}$ & $\begin{array}{c}\text { Nepal } \\
\text { (mean } \\
\pm S D \text { ) } \\
\text { or \% } \\
(\mathrm{N})\end{array}$ & $\begin{array}{l}\text { Chi- } \\
\text { Square/ } \\
\text { t-test } \\
\text { (p value) }\end{array}$ \\
\hline \multicolumn{2}{|c|}{ PSS Total score } & 18.18 & 14.40 & $2.742(0.007)^{*}$ \\
\hline \multirow[t]{2}{*}{ PSS score } & Low-<13 & $15(20)$ & $13(48)$ & \multirow[b]{2}{*}{$7.223(0.007) *$} \\
\hline & $\begin{array}{l}\text { Moderate/ } \\
\text { High->13 }\end{array}$ & $57(80)$ & $14(52)$ & \\
\hline \multirow{2}{*}{$\begin{array}{l}\text { Marital } \\
\text { status }\end{array}$} & Single(57) & \multicolumn{2}{|c|}{$17.77 \pm 5.91$} & \multirow[t]{2}{*}{$1.144(0.256)$} \\
\hline & Married(42) & 16.3 & 6.76 & \\
\hline \multirow{2}{*}{$\begin{array}{l}\text { Duration } \\
\text { of } \\
\text { experience }\end{array}$} & $<10$ years & \multicolumn{2}{|c|}{$17.37 \pm 6.28$} & \multirow[t]{2}{*}{$1.770(0.080)$} \\
\hline & $>10$ years & \multicolumn{2}{|c|}{$11.75 \pm 4.34$} & \\
\hline
\end{tabular}

Table 3 : Association between perceived stress and coping patterns in India

\begin{tabular}{|c|c|c|c|}
\hline $\begin{array}{l}\text { Individual } \\
\text { coping } \\
\text { strategies }\end{array}$ & $\begin{array}{l}\text { PSS- Low } \\
(<13) \text { n-15 }\end{array}$ & $\begin{array}{l}\text { PSS- } \\
\text { Moderate/ } \\
\text { High } \\
(>13) \text { n-57 }\end{array}$ & t-test (p-value) \\
\hline Self-distraction & $4.00 \pm 1.30$ & $5.29 \pm 1.60$ & $2.88(0.005)^{*}$ \\
\hline Active coping & $5.13 \pm 1.55$ & $4.96 \pm 1.36$ & $0.414(0.680)$ \\
\hline Denial & $2.60 \pm 0.83$ & $3.80 \pm 1.65$ & $2.78(0.008)^{*}$ \\
\hline Substance use & $2.53 \pm 0.99$ & $2.52 \pm 1.29$ & $0.02(0.985)$ \\
\hline $\begin{array}{l}\text { Emotional } \\
\text { support }\end{array}$ & $4.26 \pm 1.03$ & $4.70 \pm 1.40$ & $1.12(0.265)$ \\
\hline Disengagement & $2.86 \pm 1.24$ & $3.94 \pm 1.61$ & $2.40(0.019)^{*}$ \\
\hline Venting & $3.66 \pm 1.79$ & $4.56 \pm 1.34$ & $2.125(0.037)^{*}$ \\
\hline $\begin{array}{l}\text { Positive } \\
\text { reframing }\end{array}$ & $5.33 \pm 1.91$ & $5.35 \pm 1.65$ & $0.035(0.972)$ \\
\hline Planning & $5.40 \pm 1.59$ & $5.45 \pm 1.55$ & $0.124(0.902)$ \\
\hline Acceptance & $5.00 \pm 1.69$ & $5.66 \pm 1.73$ & $1.331(0.188)$ \\
\hline Humour & $4.40 \pm 1.99$ & $4.08 \pm 1.73$ & $0.601(0.550)$ \\
\hline Religion & $3.33 \pm 1.23$ & $4.05 \pm 1.94$ & $1.361(0.178)$ \\
\hline Self-blame & $2.93 \pm 1.16$ & $4.43 \pm 1.94$ & $2.856(0.006)^{*}$ \\
\hline $\begin{array}{l}\text { Instrumental } \\
\text { support }\end{array}$ & $4.26 \pm 1.70$ & $4.80 \pm 1.58$ & $1.155(0.252)$ \\
\hline
\end{tabular}

\subsection{Relationship between degree of perceived} stress and coping patterns (Table 3)

From the table 3 , we can see that moderate to high degree of perceived stress in the subset of Indian doctors is associated with a mixture of less adaptive and more maladaptive coping. Self-distraction, denial, disengagement, self- blame, venting are significantly associated with higher perceived stress.

However, the scenario from Nepal was found to be different. Apart from self-blame, none of the coping strategies were significantly associated with higher stress. This indicates that they use all kinds of coping strategies in equal proportion in stressful situations.

\subsection{Country-wise coping patterns (Table 4)} In order to identify the coping styles responsible for the lower and higher degree of perceived stress in the subset of doctors from Nepal and India respectively, we tried to compare two countries with respect to coping styles. It is evident from table 4 that Indian doctors use denial and self-distraction as coping strategies significantly higher than their Nepalese counterpart. Other coping measures like active coping, substance use, emotional support, disengagement, venting, positive reframing, planning, acceptance, humour, religion, selfblame, instrumental support did not differ between the countries.

Table 4 : Country of origin and relation with coping patterns

\begin{tabular}{|c|c|c|c|}
\hline $\begin{array}{l}\text { Individual coping } \\
\text { strategies }\end{array}$ & $\begin{array}{l}\text { India } \\
\mathrm{n}=72\end{array}$ & $\begin{array}{l}\text { Nepal } \\
n=27\end{array}$ & $\begin{array}{l}\text { t-test } \\
\text { (p-value) }\end{array}$ \\
\hline Self-distraction & $5.02 \pm 1.62$ & $4.07 \pm 1.38$ & $2.699(0.008)^{*}$ \\
\hline Active coping & $5.00 \pm 1.39$ & $5.07 \pm 2.05$ & $0.205(0.838)$ \\
\hline Denial & $3.55 \pm 1.59$ & $2.70 \pm 1.13$ & $2.545(0.013)^{*}$ \\
\hline Substance use & $2.52 \pm 1.23$ & $3.00 \pm 1.59$ & $1.563(0.121)$ \\
\hline $\begin{array}{l}\text { Emotional } \\
\text { support }\end{array}$ & $4.61 \pm 1.33$ & $4.18 \pm 1.27$ & $1.429(0.156)$ \\
\hline Disengagement & $3.72 \pm 1.60$ & $3.37 \pm 1.78$ & $0.944(0.348)$ \\
\hline Venting & $4.37 \pm 1.48$ & $4.07 \pm 1.49$ & $0.896(0.372)$ \\
\hline Positive reframing & $5.34 \pm 1.69$ & $5.18 \pm 1.90$ & $0.409(0.683)$ \\
\hline Planning & $5.44 \pm 1.55$ & $5.00 \pm 1.59$ & $1.258(0.211)$ \\
\hline Acceptance & $5.52 \pm 1.73$ & $5.51 \pm 1.76$ & $0.024(0.981)$ \\
\hline Humour & $4.15 \pm 1.78$ & $3.66 \pm 1.61$ & $1.239(0.218)$ \\
\hline Religion & $3.90 \pm 1.83$ & $4.18 \pm 1.86$ & $0.680(0.498)$ \\
\hline Self-blame & $4.13 \pm 1.90$ & $3.59 \pm 1.53$ & $1.302(0.196)$ \\
\hline $\begin{array}{l}\text { Instrumental } \\
\text { support }\end{array}$ & $4.69 \pm 1.61$ & $4.25 \pm 1.63$ & $1.191(0.237)$ \\
\hline
\end{tabular}

\subsection{Differences in coping patterns based on stream of post-graduation (Table 5)}

When coping patterns of both clinical and nonclinical doctors from India were compared, no significant association was found. We compared the two stream of post-graduation(clinical and 
non-clinical), there was no significant variation in type of coping in the sample of Indian doctors. In contrast to the findings from India, few differences were found in the coping patterns of the subset of Nepalese doctors. As evident from table 5, clinical doctors from Nepal used emotional support and planning at a significantly higher rate than non-clinical doctors. This is suggestive of use of more adaptive patterns of coping by clinical doctors of Nepal.

\section{Table 5: Coping of Nepalese doctors on the basis of stream of practice}

\begin{tabular}{|l|l|l|l|}
\hline $\begin{array}{l}\text { Individual } \\
\text { coping } \\
\text { strategies }\end{array}$ & $\begin{array}{l}\text { Clinical } \\
\mathrm{n}=20\end{array}$ & $\begin{array}{l}\text { Non- } \\
\text { clinical } \\
\mathrm{n}=7\end{array}$ & $\begin{array}{l}\mathrm{t} \text {-test } \\
\text { (p-value) }\end{array}$ \\
\hline Self-distraction & $4.25 \pm 1.25$ & $3.57 \pm 1.71$ & $1.121(0.273)$ \\
\hline Active coping & $5.35 \pm 1.98$ & $4.28 \pm 2.21$ & $1.188(0.246)$ \\
\hline Denial & $2.65 \pm 1.03$ & $2.85 \pm 1.46$ & $0.408(0.687)$ \\
\hline Substance use & $3.10 \pm 1.71$ & $2.71 \pm 1.25$ & $0.544(0.591)$ \\
\hline $\begin{array}{l}\text { Emotional } \\
\text { support }\end{array}$ & $4.50 \pm 1.23$ & $3.28 \pm 0.95$ & $2.356(0.027)^{*}$ \\
\hline Disengagement & $3.05 \pm 1.57$ & $4.28 \pm 2.13$ & $1.631(0.115)$ \\
\hline Venting & $4.05 \pm 1.19$ & $4.14 \pm 2.26$ & $0.139(0.891)$ \\
\hline $\begin{array}{l}\text { Positive } \\
\text { reframing }\end{array}$ & $5.50 \pm 1.90$ & $4.28 \pm 1.70$ & $1.487(0.149)$ \\
\hline Planning & $5.50 \pm 1.39$ & $3.57 \pm 1.27$ & $3.213(0.004)^{* *}$ \\
\hline Acceptance & $5.60 \pm 1.63$ & $5.28 \pm 2.21$ & $0.399(0.693)$ \\
\hline Humour & $3.80 \pm 1.43$ & $3.28 \pm 2.13$ & $0.717(0.480)$ \\
\hline Religion & $4.30 \pm 1.97$ & $3.85 \pm 1.57$ & $0.534(0.598)$ \\
\hline Self-blame & $3.40 \pm 1.31$ & $4.14 \pm 2.03$ & $1.114(0.276)$ \\
\hline $\begin{array}{l}\text { Instrumental } \\
\text { support }\end{array}$ & $4.45 \pm 1.70$ & $3.71 \pm 1.38$ & $1.028(0.314)$ \\
\hline
\end{tabular}

${ }^{*}$-significant at $p<0.05$ (two tailed); ${ }^{* *}$ - significant at $p<0.005$ (two tailed); ${ }^{* * *}$ - significant at $p<0.001$ (two tailed)

\section{Table 6: Coping Clusters and Perceived stress}

\begin{tabular}{|c|c|c|c|}
\hline $\begin{array}{l}\text { Coping } \\
\text { clusters }\end{array}$ & $\begin{array}{l}\text { PSS score- } \\
<13 \\
\text { (low stress) }\end{array}$ & $\begin{array}{l}\text { PSS score- } \\
>13 \\
\text { (moderate/ } \\
\text { high stress) }\end{array}$ & $\begin{array}{l}\text { t-test } \\
\text { (p value) }\end{array}$ \\
\hline $\begin{array}{l}\text { Seeking } \\
\text { social } \\
\text { support }\end{array}$ & $15.82 \pm 4.40$ & $17.94 \pm 4.20$ & $2.230(0.028)^{*}$ \\
\hline $\begin{array}{l}\text { Problem } \\
\text { solving }\end{array}$ & $10.03 \pm 3.08$ & $10.46 \pm 2.65$ & $0.692(0.491)$ \\
\hline Avoidance & $14.60 \pm 3.73$ & $19.83 \pm 5.42$ & $4.672(<0.001)^{* * *}$ \\
\hline $\begin{array}{l}\text { Positive } \\
\text { thinking }\end{array}$ & $14.39 \pm 4.11$ & $15.02 \pm 3.58$ & $0.761(0.448)$ \\
\hline
\end{tabular}

\subsection{Association between coping clusters and perceived stress in all samples (Table 6)}

When all the 14 coping strategies were grouped as per the well-known four clusters (Baumstarck et al., 2017) like social support, problem solving, avoidance and positive thinking, it was found that avoidance significantly increased when degree of perceived stress escalated. Significant use of avoidance as coping in the situation of high perceived stress remained true even when the data was compared separately for both the countries.

Table 7: Correlations among different variables (only positive findings shown in the table)

\begin{tabular}{|c|c|c|c|c|}
\hline Variable & $\begin{array}{l}\text { PSS total } \\
\mathrm{r}(\mathrm{p} \text { value })\end{array}$ & $\begin{array}{l}\text { Country } \\
\text { (Nepal) }\end{array}$ & Gender & $\begin{array}{l}\text { Duration } \\
\text { of } \\
\text { experience }\end{array}$ \\
\hline Self-blame & $\begin{array}{l}0.475 \\
(<0.001)^{\star * *}\end{array}$ & - & - & - \\
\hline Venting & $\begin{array}{l}0.384 \\
(<0.001)^{\star * *}\end{array}$ & - & - & - \\
\hline $\begin{array}{l}\text { Disengage } \\
\text { ment }\end{array}$ & $\begin{array}{l}0.410 \\
(<0.001)^{* * *}\end{array}$ & - & - & - \\
\hline $\begin{array}{l}\text { Emotional } \\
\text { support }\end{array}$ & $\begin{array}{l}0.205 \\
(0.042)^{*}\end{array}$ & - & - & - \\
\hline $\begin{array}{l}\text { Substance } \\
\text { use }\end{array}$ & $\begin{array}{l}0.206 \\
(0.041)^{*}\end{array}$ & - & $\begin{array}{l}-290 \\
(0.004)^{* *}\end{array}$ & - \\
\hline Denial & $\begin{array}{l}0.456 \\
(<0.001)^{* * *}\end{array}$ & $\begin{array}{l}-0.250 \\
(0.013)^{*}\end{array}$ & - & - \\
\hline $\begin{array}{l}\text { Self- } \\
\text { distraction }\end{array}$ & $\begin{array}{l}0.458 \\
(<0.001)^{* * *}\end{array}$ & $\begin{array}{l}-0.264 \\
(0.008)^{*}\end{array}$ & - & - \\
\hline $\begin{array}{l}\text { Positive } \\
\text { reframing }\end{array}$ & - & - & - & $\begin{array}{l}-0.242 \\
(0.016)^{*}\end{array}$ \\
\hline $\begin{array}{l}\text { Active } \\
\text { coping }\end{array}$ & - & - & - & $\begin{array}{l}-0.262 \\
(0.009)^{*}\end{array}$ \\
\hline PSS total & - & $\begin{array}{l}-0.268 \\
(0.007)^{*}\end{array}$ & - & \\
\hline
\end{tabular}

\subsection{Correlation among stress, coping and socio-demographic variables (Table 7)}

Higher degree of perceived stress showed positive correlation with several coping strategies likeself-blame, venting, disengagement, emotional support, substance use, denial and self-distraction. It is worthy to note that else than venting, all of the above strategies are part of avoidance i.e. maladaptive. Two type of avoidant coping i.e. self-distraction and denial were found to be negatively 
correlated with Nepal. Male gender correlated strongly with substance use as coping. Shorter duration of experience was negatively correlated with use of positive reframing and active coping which implies that younger individuals use these coping patterns less frequently.

\section{DISCUSSION:}

The present study unfolded several associations between levels of stress and various coping strategies with respect to sociodemographic and several other variables. Though we could manage only 99 as a final sample out of 250 expected subjects, we were successful in accumulating data from diverse geographical and cultural regions of India and Nepal. We received almost all responses from early career doctors probably because of our link with them and their interest in our study.

We found that most of the subset of Indian doctors (ID) were single though the age group between two countries was matched. One explanation could be that ID were more careeroriented and thus had delayed marriages. This is true as a matter of priority rather than preference for most of the people here. However, there was no significant association between being single and being stressed. Another meaningful finding was that ID perceived more stressthan Nepalese doctors (ND) irrespective of stream of practice (clinical Vs non-clinical). We believe that it was related to the third finding that most of ID fell in the range of moderate-high perceived stress than ND. The fourth important finding was that doctors in their early course of career were found to perceive more stress than their experienced counterparts. Thus, we want to say that all the above four results support the same line of evidence and generate a hypothesis. We also found a valued result that in ID, 'avoidance' coping increased significantly when their stress was in moderate-high range. This avoidance included self distraction, denial, disengagement and self blame unlike ND who had only shown association between coping of self blame and higher moderate-high stress. The correlation analysis also supported the finding when high degree of stress showed positive correlation with above 'avoidance' coping.

In addition to above points, we would also like to highlight a cultural and behavioural pattern of doctors in this region. Though the stress in ND was less than ID, Nepalese clinicians (NDC) perceived more stress that non-clinician i.e. basic science doctors (ND-NC).

\section{CONCLUSION:}

Findings of the current study can improve the understanding of the degree of stress and the coping patterns among the post graduate doctors. Doctors themselves need to maintain their mental composure in order to serve the society in a better way. So, understanding their faulty coping and addressing them is required for the betterment of doctors and later their clients. It cannot be denied that violence on doctors can decrease if working doctor is less stressed.

Our study had following strengths. Inclusion of a varied and diversified group of post graduate doctors helps us to understand the scenario as a whole, unlike the previous studies which have restricted themselves to a particular group of doctors. Comparison of the level of stress and various coping styles across countries helps us to understand the roots of these differences in a better way thus paving our way towards addressing them by future interventions. We had eliminated the interviewers' bias by making this survey online.

It is needless to say that we were not immune to limitations. Despite wide spread of samples small sample size prevented us from generalizing our findings. Randomization would have been better sample selection method. Cross sectional assessment might have missed out the periods of stress outside the study period leading to false negative results in some subjects.

ACKNOWLEDGEMENT: The authors want to acknowledge all the doctors who spent their valuable time taking part in the survey.

\section{CONFLICT OF INTEREST: None}

\section{REFERENCES:}

1. Ambesh P. Violence against doctors in the Indian subcontinent: A rising bane. Indian Heart J. 2016 Sep - Oct; 68(5):749-50.

2. Dey S, Govt plans law as attacks on doctors by patients' kin rise. The Times of India [newspaper on the Internet]. 2017 Jan 3 [cited 2018 Aug 19]. Available

from 
http://timesofindia.indiatimes.com/india/govtplans-law-as-attacks-on-doctors-by-patients-kinrise/articleshow/56303141.cms

3. Doolittle BR, Windish DM, Seelig CB. Burnout, coping, and spirituality among internal medicine resident physicians. J Grad Med Educ. 2013 Jun;5(2):257-61.

4. Hutchinson TA, Haase S, French S, McFarlane TA. Stress, Burnout and Copingamong Emergency Physicians at a Major Hospital in Kingston, Jamaica. West Indian Med J. 2014 Jun;63(3):262-6

5. Spiliopoulos K, Gansera L, Weiland HC, Schuster T, Eichinger W, Gansera B. Chronic stress and coping among cardiac surgeons: a single center study. Rev Bras Cir Cardiovasc. 2014 Jul-Sep;29(3):308-15.

6. Liu CH, Tang WR, Weng WH, Lin YH, Chen CY. The process of coping with stress by Taiwanese medical interns: a qualitative study. BMC Med Educ. 2016 Jan 12;16:10.

7. Tavakoli Z, Montazeri A, Farshad AA, Lotfi Z, Hassim IN. Sources of Stress and Coping Strategies among Iranian Physicians. Glob J Health Sci.2017;9(1):120-29.

8. Alosaimi FD, Almufleh A, Kazim S, Aladwani B. Stress-coping strategies among medical residents in Saudi Arabia: A cross-sectional national study. Pak J Med Sci. 2015;31(3):504-9

9. Bhadania S, Parikh M, Vankar GK. Stress and Coping among Resident Doctors. Archives of Indian Psychiatry 2011;13:45.

10. Saini NK, Agrawal S, Bhasin SK, Bhatia MS, Sharma AK. Prevalence of stressamong resident doctors working in Medical Colleges of Delhi. Indian J PublicHealth. 2010 Oct-Dec;54(4):21923.

11. Sathiya N, Ruwaidha R, Nusrath FS, Fathima F, Gomathy T, Shailendra HK. Perceived Stress Levels And its Sources Among Doctors and Nurses Working In A Tertiary Care Teaching Hospital, Kancheepuram, Tamil Nadu. Ntl J Community Med 2016 July; 7(7):603-8.

12. Kunwar D, Risal A, E Koirala S. Study of depression, anxiety and stress among the medical students in two medical colleges of Nepal. Kathmandu Univ Med J 2016 Jan;53(1):22-6.

13. Sreeramareddy CT, Shankar $P R$, Binu VS, Mukhopadhyay C, Ray B, Menezes RG. Psychological morbidity, sources of stress and coping strategies among undergraduate medical students of Nepal. BMC Med Educ. 2007 Aug $2 ; 7: 26$.

14. Goldberg DP, Gater R, Sartorius N, Ustun TB, Piccinelli $M$, Gureje $O$, et al. The validity of two versions of the GHQ in the WHO study of mental illness in general health care. Psychol Med. 1997 Jan;27(1):191-7.
15. Lee EH. Review of the psychometric evidence of the perceived stress scale.AsianNurs Res (Korean Soc Nurs Sci). 2012 Dec;6(4):121-7.

16. Baumstarck $K$, Alessandrini M, Hamidou Z, Auquier P, Leroy T, Boyer L. Assessment of coping: a new french four-factor structure of the brief COPE inventory. Health Qual Life Outcomes. 2017 Jan 11;15(1):8. 